\title{
USE OF RETINOIDS DURING OOCYTE MATURATION DIMINISHES APOPTOSIS IN CAPRINE EMBRYOS
}

\author{
Juliana C. Z. CONCEIÇÃO ${ }^{1}$, Marcelo T. MOURA ${ }^{1}$, José C. FERREIRA-SILVA ${ }^{1}$, \\ Pamela Ramos-Deus ${ }^{1}$, Priscila G. C. SILVA ${ }^{1}$, Ludymila F. CANTANHÊDE ${ }^{1}$, \\ Ricardo M. Chaves ${ }^{2}$, Paulo F. LIMA ${ }^{1}$ and Marcos A. L. OliveIRA ${ }^{1 *}$ \\ ${ }^{1}$ Department of Veterinary Medicine, Federal Rural University of Pernambuco, Av. Dom \\ Manoel de Medeiros, s/n, Dois Irmãos, CEP 52171-900 Recife, Pernambuco, Brazil; \\ ${ }^{2}$ Laboratory of Animal Reproduction, University Estadual do Maranhão, São Luís, Brazil
}

(Received 9 September 2014; accepted 17 February 2015)

\begin{abstract}
Exposure of caprine oocytes and embryos to retinoids enhances embryonic development, but the mechanisms governing this phenomenon have not been characterised. The aim of the present study was to evaluate if the incidence of apoptosis is affected by the addition of retinyl acetate (RAc) and 9-cis-retinoic acid (RA) during in vitro maturation (IVM) of caprine oocytes. Embryonic development was recorded on days 3 and 8 post-fertilisation, and apoptosis was measured by caspase activity and DNA fragmentation (TUNEL assay). Control zygotes had lower capacity to cleave and reach the blastocyst stage $(24.45 \pm 2.32$ and $5.32 \pm$ 0.81 , respectively) than those of RAc- $(29.96 \pm 1.62$ and $7.94 \pm 0.93$, respectively) and RA-treated groups (30.12 \pm 1.51 and $7.36 \pm 1.02$, respectively). Oocytes and blastocysts positive for TUNEL assay were more frequent, respectively, in the controls $(8.20 \pm 0.78,8.70 \pm 1.05)$ than in RAc $(5.60 \pm 0.52,4.80 \pm 0.51)$ and RA $(6.40 \pm 0.69,5.40 \pm 0.69)$. Caspase activity did not differ between control oocytes $(7.20 \pm 0.91), \operatorname{RAc}(6.60 \pm 0.68)$ and RA $(7.30 \pm 0.67)$, but it was reduced in RAc- $(5.05 \pm 0.62)$ and RA-treated blastocysts $(5.75 \pm 0.22)$ compared to controls $(8.35 \pm 0.71)$. These results indicate that the addition of retinoids during IVM increases the developmental potential of goat embryos with a concomitant reduction in apoptosis rates.
\end{abstract}

Key words: In vitro maturation, goat, embryogenesis, programmed cell death, vitamin A

Caprine production is an economically relevant activity and for a few decades, techniques such as artificial insemination and embryo transfer have been extensively used. More recently, technologies based on in vitro production (IVP) of caprine embryos have received increasing attention to further improve genetic gain in breeding schemes, and to generate cloned and/or transgenic goats (Keefer et al., 2001; Baldassarre et al., 2004; Chiamenti et al., 2010, 2013). Despite these advances, caprine IVP-based technologies are hampered by low efficiency (Bal-

*Corresponding author; E-mail: maloufrpe@uol.com.br; Phone/Fax: 0055 (81) 3320-6415 
dassarre and Karatzas, 2004), which is partly due to the limited understanding of species-specific requirements for in vitro oocyte maturation, fertilisation, and embryo culture.

A widely used approach to increase oocyte competence and embryonic development in vitro is to provide essential nutrients or survival factors. In goats, several reports have demonstrated that factors such $\alpha$-lipoic acid, activin-A and retinoids enhance embryonic development when supplemented during oocyte maturation and/or embryo culture (Bormann et al., 2003; Chiamenti et al., 2010; Kwong et al., 2012; Zhang et al., 2013; Hammami et al., 2014). Vitamin A and its physiological metabolites, collectively known as retinoids, play important roles in embryonic morphogenesis and reproductive physiology as a mitogenic and differentiation stimulus (Hofmann and Eichele, 1994). However, the data regarding retinoids for caprine IVP are conflicting. Duque et al. (2002b) reported that addition of 9-cis-retinoic acid is beneficial to embryonic development in a quantitative and qualitative manner. Similar results were described by Lima et al. (2006) in bovine and Chiamenti et al. (2010) in caprine embryos, due to the fact that retinoids synchronise cellular events that trigger oocyte maturation, increase oocyte ability to be fertilised and potentiate further preimplantation embryonic development (Duque et al., 2002a; Lima et al., 2004; Lima et al., 2006; Chiamenti et al., 2010, 2013). However, Cavalcanti Neto (2004) did not observe any effect of retinyl acetate or 9-cis-retinoic acid on caprine oocyte nuclear and cytoplasmatic maturation. The understanding of the mechanism underlying retinoid treatment may guide future research in order to address this controversy.

The objective of the present study was to test if the addition of retinyl acetate (RAc) or 9-cis-retinoic acid (RA) during the in vitro maturation (IVM) of oocytes contributes to apoptosis inhibition in caprine oocytes and embryos.

\section{Materials and methods}

\section{Oocyte retrieval and in vitro maturation}

Caprine ovaries were obtained at local slaughterhouses (Pernambuco State, Brazil), and transported to the laboratory at $30{ }^{\circ} \mathrm{C}$ in $0.9 \% \mathrm{NaCl}$ solution containing $30 \mu \mathrm{g} \mathrm{mL}^{-1}$ of gentamicin sulphate. Cumulus-oocyte complexes (COC) were recovered from 2- to 6-mm follicles with an $18 \mathrm{G}$ needle in washing medium [ $8.0 \mathrm{mg}$ of sodium bicarbonate, $45.0 \mathrm{mg}$ of glucose, $5.6 \mathrm{mg}$ of sodium pyruvate, $11.9 \mathrm{mg}$ of HEPES, $2.5 \mathrm{mg}$ of gentamicin sulphate and $20.0 \mathrm{mg}$ of polyvinyl alcohol (PVA)] in $50 \mathrm{~mL}$ of TALP.

Oocytes were selected, washed and placed in maturation medium covered with sterile paraffin oil (Sigma-Aldrich) as previously described by Chiamenti et al. (2010). The maturation medium consisted of TCM-199 (Sigma-Aldrich) supplemented with $50 \mu \mathrm{g} \mathrm{mL}^{-1}$ of sodium pyruvate, $2.6 \mathrm{mg} \mathrm{mL}^{-1}$ sodium bicarbonate, 
$50 \mu \mathrm{g} \mathrm{mL}^{-1}$ of gentamicin sulphate, $5.0 \mu \mathrm{g} \mathrm{mL}^{-1}$ Pluset $^{\circledR}$ and $1 \mathrm{mg} \mathrm{mL}^{-1}$ PVA. Oocytes were randomly distributed into the following groups: control $(n=1380)$, $0.3 \mu \mathrm{M}$ retinyl acetate $(\mathrm{RAc})(\mathrm{n}=1334)$, and $0.5 \mu \mathrm{M}$ 9-cis-retinoic acid (RA) $(\mathrm{n}=1358)$ in ten replicates. Furthermore, oocytes were incubated at $39^{\circ} \mathrm{C}$ with $5 \% \mathrm{CO}_{2}$ at saturated humidity for $24 \mathrm{~h}$. After maturation and analysis of cumulus expansion, oocytes were randomly selected for caspase activity assay $(\mathrm{n}=100)$, DNA fragmentation test (TUNEL assay, $\mathrm{n}=100$ ), and the remaining oocytes were destined for in vitro fertilisation (IVF).

\section{In vitro fertilisation}

Caprine IVF was performed as described earlier (Cavalcanti Neto, 2004; Chiamenti et al., 2010). Briefly, $0.1 \mathrm{~mL}$ of freshly collected semen was deposited in $1.5 \mathrm{~mL}$ of modified defined medium (mDM) (Keskintepe et al., 1998; Chiamenti et al., 2010). Viable sperm cells were selected by the swim-up method. After $45 \mathrm{~min}, 0.8 \mathrm{~mL}$ was aspirated from the upper layer and centrifuged at $350 \mathrm{~g}$ for $10 \mathrm{~min}$. The pellet was supplemented with $200 \mu \mathrm{L}$ of mDM containing $10 \mu \mathrm{g} \mathrm{mL}{ }^{-1}$ of heparin.

Oocytes were assessed for cumulus expansion before IVF, and COC that did not expand were discarded. Pools of 25 oocytes were transferred to $\mathrm{mDM}$ containing a final sperm suspension of $2.0 \times 10^{6}$ spermatozoa $\mathrm{mL}^{-1}$ under sterile paraffin oil. Gametes were co-incubated for $18 \mathrm{~h}$.

In vitro embryo culture

Presumptive zygotes were denuded and transferred to Potassium Simplex Optimized Medium (KSOM) and co-cultured on a monolayer of oviduct cells (Chiamenti et al., 2010). After $48 \mathrm{~h}$ of embryo culture, non-cleaved zygotes were removed and $30 \%$ of embryo culture medium was replaced with fresh KSOM. Embryonic development was recorded at day 3 (D3) and day 8 (D8). D8 blastocysts were analysed for caspase activity and DNA fragmentation (TUNEL assay).

\section{Caspase activity}

Caspase activity was determined as described earlier (Paula-Lopes and Hansen, 2002a,b; Roth and Hansen, 2004). Briefly, oocytes were denuded and washed in PBS supplemented with $1 \mathrm{mg} \mathrm{mL}^{-1}$ polyvinylpyrrolidone (PBS-PVP) and incubated in PBS-PVP containing $5 \mu \mathrm{M}$ of PhiPhiLux-G1D2 for $40 \mathrm{~min}$ at $39^{\circ} \mathrm{C}$ (Caspase-3 Intracellular Activity Assay Kit I, Calbiochem-Merck, Darmstadt, Germany). Moreover, oocytes were washed in PBS-PVP and caspase enzymatic activity was determined by fluorescence microscopy. Oocytes and embryos were scored as positive or negative for caspase activity. Ten replicates were performed. 


\section{TUNEL assay}

The TUNEL assay was performed as previously described, with minor modifications (Paula-Lopes and Hansen, 2002a,b; Roth and Hansen, 2004). Oocytes were denuded and fixed in $4 \%$ paraformaldehyde for $1 \mathrm{~h}$ at room temperature. Oocytes were washed in PBS-PVP and incubated in permeabilisation buffer (0.5\% Triton X-100 containing $0.1 \%$ sodium citrate) for $1 \mathrm{~h}$ and stored at $4{ }^{\circ} \mathrm{C}$. Samples were further washed in PBS-PVP and incubated in terminal deoxynucleotidyl transferase enzyme solution (TUNEL) (in situ Cell Death Detection Kit, Fluorescein, Roche, Mannheim, Germany) for $1 \mathrm{~h}$ at $37^{\circ} \mathrm{C}$, were then washed in PBS-PVP and incubated with DNA-specific stain DAPI for 15 min. Oocytes were washed once more in PBS-PVP, transferred to slides with coverslips, and evaluated by fluorescence microscopy. Oocytes and embryos were scored as positive or negative for DNA fragmentation based on TUNEL. Ten replicates were performed.

\section{Statistical analysis}

Analysis of variance (ANOVA) by minimum squares method was used using PROC GLM (for fixed variables) and PROC MIXED (for fixed and random variables) from the SAS STAT package (SAS institute, Cary, NC). Before running the analysis, rough data were scored for ANOVA requirements (variables homogeneity and residues normality). Dependent and independent variables were established based on the experimental design. Statistical models considered all main effects. Differences with 5\% probability were considered significant.

\section{Results}

In order to investigate the effect of retinoid addition on the incidence of apoptosis during caprine embryonic development, in vitro embryo production was performed by adding RAc or RA to oocyte IVM medium (Table 1). A defined IVM medium was used by replacing FBS with PVA, aiming to rule out any influence of serum, due to its complex and variable composition. Moreover, RAc and RA enhanced embryonic development at cleavage and blastocysts stages (Table 1). No difference was observed in embryo yields from the RAc and RA groups.

The TUNEL assay was used to detect DNA fragmentation in oocytes and embryos (Table 2), and the incidence of DNA fragmentation in oocytes was similar between retinoid-treated groups, but lower than in the control (Table 2). When blastocysts were analysed, the RAc and RA groups had less DNA fragmentation than the controls. 
Table 1

In vitro embryo production using goat oocytes supplemented with retinyl acetate (RAc) or $0.5 \mu \mathrm{M}$ 9-cis-retinoic acid (RA)

\begin{tabular}{lcccc}
\hline Group & $\begin{array}{c}\text { Oocytes for } \\
\text { maturation } \\
(\mathrm{n})\end{array}$ & $\begin{array}{c}\text { Oocytes for } \\
\text { fertilisation } \\
(\mathrm{n})\end{array}$ & $\begin{array}{c}\text { Cleaved } \\
\mathrm{n}(\text { mean } \pm \text { SD) }\end{array}$ & $\begin{array}{c}\text { Blastocysts } \\
\mathrm{n}(\text { mean } \pm \text { SD) }\end{array}$ \\
\hline Control & 698 & 412 & $107(24.45 \pm 2.32)^{\mathrm{a}}$ & $10(05.32 \pm 0.81)^{\mathrm{a}}$ \\
RAc & 816 & 532 & $170(29.96 \pm 1.62)^{\mathrm{b}}$ & $18(07.94 \pm 0.93)^{\mathrm{b}}$ \\
RA & 863 & 561 & $179(30.12 \pm 1.51)^{\mathrm{b}}$ & $19(07.36 \pm 1.02)^{\mathrm{b}}$ \\
\hline
\end{tabular}

$\mathrm{SD}=$ standard deviation. The experiments were repeated ten times. ${ }^{\mathrm{a}, \mathrm{b}}$ Values with different superscript letters are significantly different $(\mathrm{P}<0.05)$

Table 2

Effect of retinyl acetate (RAc) and $0.5 \mu \mathrm{M}$ 9-cis-retinoic acid (RA) supplementation during oocyte maturation on DNA fragmentation in goat oocytes and blastocysts

\begin{tabular}{lcccc}
\hline Group & $\begin{array}{c}\text { Oocytes } \\
(\mathrm{n})\end{array}$ & $\begin{array}{c}\text { TUNEL-positive } \\
\text { oocytes } \\
\mathrm{n}(\mathrm{mean} \pm \mathrm{SD})\end{array}$ & $\begin{array}{c}\text { Blastocysts } \\
(\mathrm{n})\end{array}$ & $\begin{array}{c}\text { TUNEL-positive } \\
\text { blastocysts } \\
\mathrm{n}(\text { mean } \pm \mathrm{SD})\end{array}$ \\
\hline Control & 100 & $09(08.20 \pm 0.78)$ & 5 & $1(08.70 \pm 1.05)^{\mathrm{a}}$ \\
RAc & 100 & $06(05.60 \pm 0.52)$ & 9 & $1(04.80 \pm 0.51)^{\mathrm{b}}$ \\
RA & 100 & $07(06.40 \pm 0.69)$ & 10 & $1(05.40 \pm 0.69)^{\mathrm{b}}$
\end{tabular}

SD = standard deviation; terminal deoxynucleotidyl transferase enzyme solution (TUNEL). The experiments were repeated ten times. ${ }^{\mathrm{a}, \mathrm{b}}$ Values with different superscript letters are significantly different $(\mathrm{P}<0.05)$

Caspase activity was initially investigated in oocytes (Table 3). No difference was observed in the incidence of caspase activity in oocytes within groups. Moreover, caspase activity was more frequent in control than in RAc and RA blastocysts (Table 3).

Table 3

Caspase activity in goat oocytes and blastocysts after supplementation with retinyl acetate (RAc) or $0.5 \mu \mathrm{M}$ 9-cis-retinoic acid (RA) during oocyte maturation

\begin{tabular}{lcccc}
\hline Group & $\begin{array}{c}\text { Oocytes } \\
(\mathrm{n})\end{array}$ & $\begin{array}{c}\text { Caspase-positive } \\
\text { oocytes } \\
\mathrm{n}(\text { mean } \pm \mathrm{SD})\end{array}$ & $\begin{array}{c}\text { Blastocysts } \\
(\mathrm{n})\end{array}$ & $\begin{array}{c}\text { Caspase-positive } \\
\text { blastocysts } \\
\mathrm{n}(\mathrm{mean} \pm \mathrm{SD})\end{array}$ \\
\hline Control & 100 & $08(07.20 \pm 0.91)$ & 5 & $1(08.35 \pm 0.71)^{\mathrm{a}}$ \\
RAc & 100 & $07(06.60 \pm 0.68)$ & 9 & $1(05.05 \pm 0.62)^{\mathrm{b}}$ \\
RA & 100 & $08(07.30 \pm 0.67)$ & 9 & $1(05.75 \pm 0.22)^{\mathrm{b}}$ \\
\hline
\end{tabular}

$\mathrm{SD}=$ standard deviation. The experiments were repeated ten times. ${ }^{\mathrm{a}, \mathrm{b}}$ Values with different superscript letters are significantly different $(\mathrm{P}<0.05)$ 


\section{Discussion}

The effect of retinoids in vivo has been extensively described (Shaw et al., 1995; Hidalgo et al., 2002), but their benefit to caprine embryonic development in vitro remains controversial. Despite this, the data described here show that retinoids increase oocyte competence in vitro, in accordance with reports in several species such as the porcine, bovine and canine species (Almiñana et al., 2008; Deb et al., 2011, 2012; Liang et al., 2012).

Furthermore, it was sought to investigate if caprine oocyte and embryo quality is also improved by retinoids, measured by the incidence of apoptosis. Several efforts have been made to find connections between the characteristics of caprine oocytes and their apoptosis incidence as well as the influence of the latter on embryonic development. It has been shown that the diameter of healthy oocytes correlates with the incidence of apoptosis (Anguita et al., 2009), follicle size correlates with DNA fragmentation in oocytes (Romaguera et al., 2010), and glucose-6-phosphate dehydrogenase (G6PDH) activity of goat oocytes (determined by brilliant cresyl blue staining) enhances embryonic development and increases Bcl-2 expression in blastocysts (Abazari-Kia et al., 2014).

In this study, two markers of apoptosis were chosen to characterise apoptosis, namely DNA fragmentation and caspase activation, in order to avoid misleading interpretations due to other types of cell death during preimplantation development (Gjørret et al., 2003).

Apoptosis was characterised in bovine oocytes by cytoplasmic condensation and fragmentation followed by apoptotic body formation with or without DNA fragmentation (Perez et al., 1999; Mem et al., 2003). This DNA damage detected by the TUNEL assay is not always caused by the activity of effector caspases (Van Blerkom and Davis, 1998; Xu et al., 2001). Activation of apoptosis mechanisms upstream of caspase activation leads to oocyte apoptosis (Roth and Hansen, 2004). Collectively, the association of DNA damage and caspase 3 detection can successfully be used to describe apoptosis in oocytes and embryos.

The validity of the association between these two apoptosis markers is in accordance with findings described in the present report, where DNA fragmentation in caprine oocytes did overlap with caspase activity in all experimental groups. Caspase-positive oocytes displayed a broad cytoplasm without condensation, a fact that is considered normal, and were observed mainly in oocytes treated with retinoids. To the best of our knowledge, this is the first report describing changes in IVP conditions that increase embryo quantity and improve embryo quality by reducing apoptosis.

Despite the pleiotropic nature of the role of retinoids during development, it is becoming clear that cumulus cells play a major role in mediating the effects of retinoids during in vitro oocyte maturation. Gene expression analysis has revealed transcriptional changes in cumulus cells in response to retinoids that are 
related to the prevention of apoptosis: up-regulation of midkine (Gómez et al., 2003), down-regulation of aldo-keto reductase family 1 member B1 (AKR1B1), a gene potentially associated with pregnancy failure (Deb et al., 2012), and down-regulation of proto-oncogenes and extracellular signal-regulated kinases 1/2 (ERK1/2) and Janus kinase (JNK) signalling pathways (Deb et al., 2012). Retinoid-treated cumulus cells also express lower levels of initiator and effector caspases, TNF- $\alpha$, TNFR1, BAX (Deb et al., 2012; Liang et al., 2012) and higher levels of BCL-2 (Deb et al., 2012). Despite these benefits from cumulus cells, retinoid treatment did not reduce the incidence of oocyte apoptosis, due to the short interval between treatment and assessment, or because of an unknown factor. Retinoid treatment before maturation could be more effective against oocyte apoptosis (Duque et al., 2002a). The increase in blastocyst quantity and quality after retinoid treatment during oocyte maturation is in accordance with a longterm effect model.

Retinoids, when supplemented during embryo culture, require co-culture systems, at least under some experimental conditions, in order to enhance embryonic development (Lima et al., 2004; Chiamenti et al., 2010, 2013). This fact suggests that this paracrine signalling could be potentially useful for increasing embryonic development in vitro in other species and should be the focus of future research aimed at describing the molecular basis of retinoid embryotrophic properties in vitro.

Although more research is needed to mechanistically elucidate all the roles played by retinoids in enhancing caprine embryonic development in vitro, we conclude that at least part of this benefit comes from the inhibition of programmed cell death as evidenced by the reduction in the incidence of apoptosis markers.

\section{Acknowledgements}

This study was supported by CNPq and FACEPE grants. Marcelo T. Moura is a CAPES postdoctoral fellow.

\section{References}

Abazari-Kia, A. H., Mohammadi-Sangcheshmeh, A., Dehghani-Mohammadabadi, M., JamshidiAdegani, F., Veshkini, A., Zhandi, M., Cinar, M. U. and Salehi, M. (2014): Intracellular glutathione content, developmental competence and expression of apoptosis-related genes associated with G6PDH-activity in goat oocyte. J. Assist. Reprod. Genet. 31, 313-321.

Almiñana, C., Gil, M. A., Cuello, C., Caballero, I., Roca, J., Vazquez, J. M., Gomez, E. and Martinez, E. A. (2008): In vitro maturation of porcine oocytes with retinoids improves embryonic development. Reprod. Fertil. Dev. 20, 483-489.

Anguita, B., Paramio, M. T., Morató, R., Romaguera, R., Jiménez-Macedo, A. R., Mogas, T. and Izquierdo, D. (2009): Effect of the apoptosis rate observed in oocytes and cumulus cells on embryo development in prepubertal goats. Anim. Reprod. Sci. 116, 95-106. 
Baldassarre, H. and Karatzas, C. N. (2004): Advanced assisted reproduction technologies (ART) in goats. Anim. Reprod. Sci. 82-83, 255-266.

Baldassarre, H., Wang, B., Keefer, C. L., Lazaris, A. and Karatzas, C. N. (2004): State of the art in the production of transgenic goats. Reprod. Fertil. Dev. 16, 465-470.

Bormann, C. L., Ongeri, E. M. and Krisher, R. L. (2003): The effect of vitamins during maturation of caprine oocytes on subsequent developmental potential in vitro. Theriogenology 59, $1373-1380$

Cavalcanti Neto, C. C. (2004): Use of retinol for the in vitro production of goat embryos [in Portuguese]. Thesis, Belo Horizonte, Universidade Federal de Minas Gerais, Brazil.

Chiamenti, A., Aguiar Filho, C. R., Freitas Neto, L. M., Chaves, R. M., Paula-Lopes, F., Lima, P. F., Gonçalves, P. B. D. and Oliveira, M. A. L. (2010): Effects of retinoids on the in vitro development of Capra hircus embryos to blastocysts in two different culture systems. Reprod. Domest. Anim. 45, 68-72.

Chiamenti, A., Aguiar Filho, C. R., Moura, M. T., Paula-Lopes, F. F., Neves, J. P., Cavalcanti Neto, C. C., Gonçalves, P. B. D., Lima, P. F. and Oliveira, M. A. L. (2013): Use of retinyl acetate, retinoic acid and insulin-like growth factor-I (IGF-I) to enhance goat embryo production. Acta Vet. Hung. 61, 116-124.

Deb, G. K., Dey, S. R., Bang, J. I., Cho, S. J., Park, H. C., Lee, J. G. and Kong, I. K. (2011): 9-cis retinoic acid improves developmental competence and embryo quality during in vitro maturation of bovine oocytes through the inhibition of oocyte tumor necrosis factor- $\alpha$ gene expression. J. Anim. Sci. 89, 2759-2767.

Deb, G. K., Dey, S. R., Bang, J. I., Lee, J. G. and Kong, I. K. (2012): 9-cis retinoic acid inhibits cumulus cell apoptosis during the maturation of bovine cumulus-oocyte-complexes. J. Anim. Sci. 90, 1798-1806.

Duque, P., Diez, C., Royo, L., Lorenzo, P. L., Carneiro, G., Hidalgo, C. O., Facal, N. and Gomez, E. $(2002 a)$ : Enhancement of developmental capacity of meiotically inhibited bovine oocytes by retinoic acid. Mol. Hum. Reprod. 17, 2706-2714.

Duque, P., Gomez, E., Hidalgo, C., Facal, N., Fernandez, I. and Diez, C. (2002b): Retinoic acid during in vitro maturation of bovine oocytes promotes embryonic development and early differentiation. Theriogenology 57, 364.

Gjørret, J. O., Knijn, H. M., Dieleman, S. J., Avery, B., Larsson, L. I. and Maddox-Hyttel, P. (2003): Chronology of apoptosis in bovine embryos produced in vivo and in vitro. Biol. Reprod. 69, 1193-1200.

Gómez, E., Royo, L. J., Duque, P., Carneiro, G., Hidalgo, C., Goyache, F., Lorenzo, P. L., Alvarez, I., Facal, N. and Díez, C. (2003): 9-cis-retinoic acid during in vitro maturation improves development of the bovine oocyte and increases midkine but not IGF-I expression in cumulus-granulosa cells. Mol. Reprod. Dev. 66, 247-255.

Hammami, S., Izquierdo, D., Catalá, M. G., Paramio, M. T. and Morató, R. (2014): In vitro developmental competence of prepubertal goat oocytes cultured with recombinant activin-A. Animal 8, 94-101.

Hidalgo, C., Diez, C., Duque, P., Facal, N., Prendes, J. M., Fernandez, I. and Gomez, E. (2002): Improved cumulus-oocyte complex yields from heifers treated with retinol. Theriogenology $\mathbf{5 7 ,} 672$.

Hofmann, C. and Eichele, G. (1994): The retinols, biology, chemistry and medicine. In: Sporn, M. B., Roberts, A. B. and Googman, D. S. (eds) Retinoids in Development. Raven Press, New York, NY. pp. 387-441.

Keefer, C. L., Baldassarre, H., Keyston, R., Wang, B., Bhatia, B., Bilodeau, A. S., Zhou, J. F., Leduc, M., Downey, B. R., Lazaris, A. and Karatzas, C. N. (2001): Generation of dwarf goat (Capra hircus) clones following nuclear transfer with transfected and nontransfected fetal fibroblasts and in vitro-matured oocytes. Biol. Reprod. 64, 849-856. 
Keskintepe, L., Simplício, A. A. and Brackett, B. G. (1998): Caprine blastocyst development after in vitro fertilization with spermatozoa frozen in different extenders. Theriogenology 49, $1265-1274$.

Kwong, P. J., Abdullah, R. B. and Wan Khadijah, W. E. (2012): Increasing glucose in KSOMaa basal medium on culture Day 2 improves in vitro development of cloned caprine blastocysts produced via intraspecies and interspecies somatic cell nuclear transfer. Theriogenology 78, 921-929.

Liang, S., Kang, J., Jin, H., Liu, X., Li, J., Li, S., Lu, Y., Wang, W. and Yin, X. J. (2012): The influence of 9-cis-retinoic acid on nuclear and cytoplasmic maturation and gene expression in canine oocytes during in vitro maturation. Theriogenology 77, 1198-1205.

Lima, P. F., Oliveira, M. A. L., Gonçalves, P. B. D., Montagner, M. M., Reichenbach, H-D., Weppert, M., Cavalcanti Neto, C. C., Pina, V. M. R. and Santos, M. H. B. (2004): Effects of retinol on the in vitro development of Bos indicus embryos to blastocysts in two different culture systems. Reprod. Domest. Anim. 39, 356-360.

Lima, P. F., Oliveira, M. A. L., Santos, M. H. B., Reichenbach, H-D., Weppert, M., Paula-Lopes, F., Cavalcanti Neto, C. C. and Gonçalves, P. B. D. (2006): Effect of retinoids and growth factor on in vitro bovine embryos produced under chemically defined conditions. Anim. Reprod. Sci. 95, 184-192.

Mem, H., Monson, R. L., Parrish, J. J. and Rutledge, J. J. (2003): Degeneration of cryopreserved bovine oocytes via apoptosis during subsequent culture. Cryobiology 47, 73-81.

Paula-Lopes, F. F. and Hansen, P. J. (2002a): Apoptosis is an adaptative response in bovine preimplantation embryos that facilitates survival after heat shock. Biochem. Biophys. Res. Commun. 295, 37-42.

Paula-Lopes, F. F. and Hansen, P. J. (2002b): Heat shock-induced apoptosis in preimplantation bovine embryos is a developmentally regulated phenomenon. Biol. Reprod. 66, 1169-1177.

Perez, G. I., Tao, X. J. and Tilly, J. L. (1999): Fragmentation and death (a.k.a. apoptosis) of ovulated oocytes. Mol. Hum. Reprod. 5, 414-420.

Romaguera, R., Casanovas, A., Morató, R., Izquierdo, D., Catalá, M., Jimenez-Macedo, A. R., Mogas, T. and Paramio, M. T. (2010): Effect of follicle diameter on oocyte apoptosis, embryo development and chromosomal ploidy in prepubertal goats. Theriogenology 74, 364-373.

Roth, Z. and Hansen, P. J. (2004): Involvement of apoptosis in disruption of developmental competence of bovine oocytes by heat shock during maturation. Biol. Reprod. 71, 1898-1906.

Shaw, D. W., Farin, P. W., Washburn, S. P. and Britt, J. H. (1995): Effect of retinol palmitate on ovulation rate and embryo quality in superovulated cattle. Theriogenology 44, 51-58.

Van Blerkom, J. and Davis, P. W. (1998): DNA strand break and phosphatidylserine redistribution in newly ovulated and culture mouse and human oocytes: occurrence and relationship to apoptosis. Hum. Reprod. 13, 1317-1324.

Xu, J. S., Chang, T. M., Chan, T. H., Ho, P. C. and Yeung, W. S. B. (2001): The incidence of cytoplasmic fragmentation in mouse embryos in vitro is not affected by inhibition of caspase activity. Fertil. Steril. 5, 986-991.

Zhang, H., Wu, B., Liu, H., Qiu, M., Liu, J., Zhang, Y. and Quan, F. (2013): Improving development of cloned goat embryos by supplementing $\alpha$-lipoic acid to oocyte in vitro maturation medium. Theriogenology 80, 228-233. 